\title{
ERß decreases the invasiveness of triple-negative breast cancer cells by regulating mutant p53 oncogenic function
}

\author{
Igor Bado', Fotis Nikolos ${ }^{1}$, Gayani Rajapaksa ${ }^{1}$, Jan-Åke Gustafsson ${ }^{1}$, Christoforos \\ Thomas $^{1}$ \\ ${ }^{1}$ Department of Biology and Biochemistry, Center for Nuclear Receptors and Cell Signaling, University of Houston, Houston, \\ Texas 77204, USA
}

Correspondence to: Christoforos Thomas, e-mail: chthomas@uh.edu

Keywords: estrogen receptor $\beta$, mutant $p 53$, triple-negative breast cancer, cell invasion, 063

Received: November 05, 2015

Accepted: January 29, 2016

Published: February 10, 2016

\section{ABSTRACT}

Most $(80 \%)$ of the triple-negative breast cancers (TNBCs) express mutant p53 proteins that acquire oncogenic activities including promoting metastasis. We previously showed that wild-type ERß (ERß1) impedes epithelial to mesenchymal transition (EMT) and decreases the invasiveness of TNBC cells. In the present study we searched for signaling pathways that ER $\beta 1$ uses to inhibit EMT and invasion in TNBC cells. We show that ERß1 binds to and opposes the transcriptional activity of mutant p53 at the promoters of genes that regulate metastasis. p63 that transcriptionally cooperates with mutant p53 also binds to ER 31 . Downregulation of p63 represses the epithelial phenotype of ERß1-expressing cells and alters the expression of mutant p53 target genes. These results describe a novel mechanism through which ERß1 can disturb oncogenic signals to inhibit aggressiveness in TNBCs.

\section{INTRODUCTION}

Of all breast cancers, clinical management of the basal-like subtype is particularly challenging due to lack of effective targeted therapies. Most of basal-like tumors are typically negative for estrogen receptor $\alpha(E R \alpha)$, progesterone receptor and human epidermal growth factor receptor (HER)-2 and often referred to as triple-negative breast cancers (TNBCs). Basal-like cancers occur more frequently in younger women, they are biologically aggressive and often develop distant metastases $[1,2]$. Most $(80 \%)$ of these highly aggressive tumors harbor mutations in $p 53$ gene [1]. The majority of these mutations result in the expression of a protein with single amino acid substitutions in the DNA-binding domain (DBD) [3]. Because of alterations in the DNA-binding activity or the structure of the DBD, mutant p53 proteins either lose the tumor suppressor activity or acquire oncogenic function. Tissue culture and animal-based studies have demonstrated that mutant $\mathrm{p} 53$ proteins gain oncogenic properties that are independent of loss of wild-type p53 function. Expression of mutant p53 in p53 null cell lines promotes proliferation and invasion [4]. In mice harboring tumor-associated p53 mutations there is development of more invasive and metastatic tumors than in p53 null mice $[5,6]$.
All p53 family members exist as N-terminal variants derived from alternative promoter transcription (full length (TA) and truncated $(\Delta \mathrm{N})$ ) and $\mathrm{C}$-terminal isoforms $(\alpha, \beta, \gamma)$ produced by alternative splicing in the $\mathrm{C}$-terminus. Interactions between the same or different family members represent one of the mechanisms that regulate their activity [7-9]. Only p53 with point mutations in the DNA binding domain that alter its conformation can interact with p63 and p73. TAp63 regulates gene expression to decrease the activity of cell surface receptors including EGFR and cell invasion [10-13]. By binding to p63 and preventing its normal transcriptional activity, mutant $\mathrm{p} 53$ promotes cell invasion $[10,12,14,15]$. Although mutant $p 53$ retains some DNA binding activity, it tethers to specific DNA sequences through other transcription factors including p63. This may account for the shared mutant p53 and p63 target genes that were identified in cancer cells [16]. Other mutant p53interacting proteins that alter its gain-of-function include MDM2, PIN1, ANKRD11 and SMAD2 [7, 17, 18].

Another regulator of p53 is estrogen. Estrogen signaling is mediated through two estrogen receptor (ER) subtypes, $\mathrm{ER} \alpha$ and $E R \beta$. ER $\alpha$ is the principal biomarker for directing endocrine therapies and the primary therapeutic target in breast cancer. Wild-type ER $\beta$ (ER $\beta 1)$ correlates with better survival in patients with TNBC [10, 19-21]. 
Interestingly, ERs have been shown to alter wild-type and mutant p53 transactivation. They transcriptionally cooperate with p53 through two mechanisms. One functions when ERs and p53 bind to their cognate response elements without a physical interaction [22] and the other requires binding of $E R \alpha$ to wild-type p53 which results in repression of p53 function [23-25]. In contrast to ER $\alpha$, the interaction between ER $\beta$ and p53 and its effects on transcription have not been studied and is the subject of the present study. We, and others, have previously shown that ER $\beta 1$ impedes epithelial to mesenchymal transition (EMT) and decreases the invasiveness of mutant p53 TNBC cells by repressing EGFR signaling [26, 27]. However, the mechanism underlying the association of ER $\beta 1$ with the decreased EGFR activity and cell invasion has remained elusive. In the present study, we demonstrate the inhibition of mutant p53 oncogenic function as one of the mechanisms employed by ER $\beta 1$ to decrease invasion in TNBC cells.

\section{RESULTS}

\section{Anti-migratory activity of ER $\beta 1$ correlates with inhibition of mutant p53 function}

In the present study we searched for ER $\beta 1$ interacting proteins and target genes that may account for the decreased invasiveness of ER $\beta 1$-expressing TNBC cells $[26,27]$. We focused on mutant p53 signaling since p53 is frequently mutated in TNBC and mutant p53 proteins promote tumor metastasis $[10,12,17,28]$. We used as an indicator of mutant p53 gain-of-function the expression of genes that are regulated by mutant $\mathrm{p} 53$. We focused on those genes that inhibit metastasis in breast cancer including SHARP-1 and the ER $\alpha$-regulated $C C N G 2$ $[3,10,29-31]$ and the pro-metastatic factor Follistatin [32]. As shown in Figure 1A (top), expression of ER $\beta 1$ in mutant $\mathrm{p} 53$ (p53280K)-expressing MDA-MB-231 cells upregulated SHARP-1, CCNG2 and the tumor suppressor ADAMTS9 [33] and downregulated Follistatin. The relevance of mutant p53 to the expression of these genes was further demonstrated by the upregulation of SHARP1, ADAMTS9 and GRP87 following knockdown of mutant p53 in MDA-MB-231 cells (Figure 1A, bottom). A similar gene expression signature was observed following upregulation of ER $\beta 1$ in another TNBC cell line. BT549 cells have mesenchymal-like morphology and express a different hot spot p53 mutant (p53249S). The changes in the expression of SHARP-1, CCNG2 and Follistatin mRNAs were also confirmed at the protein level (Figure 1B, top). In addition to altering the expression of metastasis-associated genes, ER $\beta 1$ induced epithelial transformation in these cells as it did in MDA-MB-231 cells (Figure 1B, bottom) [27]. In contrast to mutant p53expressing TNBC cells, ER $\beta 1$ did not alter the epitheliallike morphology of the p53 null SUM159 TNBC cells (Figure 1C, top). In these cells, ER $\beta 1$ was found to regulate the expression of Follistatin, ADAMTS9 and
$C C N G 2$ in opposite direction compared with the mutant p53-expressing cells (Figure 1C, bottom). This may be associated with a different mode of gene regulation in ER $\beta 1$-expressing cells that lack p53 and may depend on p63 isoforms that target the same group of genes and show unique expression in these cells (Figure 1D) [10]. We also analyzed the same genes in MDA-MB-231 cells with differential expression of ER $\beta 1$. Gradual upregulation of ER $\beta 1$ resulted in a progressive increase of ADAMTS9, GRP87 and CCNG2 and decrease of Follistatin levels (Figure 1E and Supplementary Figure 1). We previously showed that the levels of the transfected ER $\beta 1$ in TNBC cells are comparable with those of the endogenous receptor in MCF-7 cells [27]. In the present study, we compared the levels of the transfected ER $\beta 1$ in TNBC cells with the expression of endogenous ER $\alpha$ in MCF-7 cells, an indicator of biologically relevant ER expression in breast cancer cells. As shown in Figure 1F, the transfected ER $\beta 1$ in TNBC cells is expressed at lower levels compared with the endogenous ER $\alpha$ in MCF-7 cells. Despite an expected variation in the expression due to transfection, these results indicate the relevance of the ER $\beta 1$ expression system to human breast cancer cells.

To corroborate our findings, we examined the effects of ER $\beta 1$ upregulation on mutant p53 function in H1299 lung cancer cells. These cells are null for $\mathrm{p} 53$ and undergo mesenchymal reprogramming after mutant $\mathrm{p} 53$ expression $[10,12,34]$. We established pooled colony cell lines that express the frequently altered in human cancers p 53 gain-offunction mutants $\mathrm{p} 53143 \mathrm{~A}$ and $\mathrm{p} 53175 \mathrm{H}$ alone or together with ER $\beta 1[35,36]$. Upregulation of ER $\beta 1$ reversed the mutant p53-induced mesenchymal-like phenotype (Figure 2A and $2 \mathrm{~B}$ ), the increase in cell migration and invasion (Figure 2C and 2D, left) [10, 12], the downregulation of the epithelial marker E-cadherin and upregulation of EGFR signaling (Figure 2D, right). In addition, expression of ER $\beta 1$ reversed the downregulation of SHARP-1 and CCNG2 and upregulation of Follistatin. A difference in the expression pattern of ADAMTS9 and GRP87 may be associated with a different function of $\mathrm{p} 53$ mutants in the presence of varying expression of TA and $\triangle \mathrm{Np} 63$ (Figures $2 \mathrm{E}$ and $2 \mathrm{~F}$ ).

\section{ERß1 interacts with mutant p53}

A transcriptional cooperation between ER $\beta$ and p53 was previously associated with the binding of the proteins to their cognate response elements [22]. To examine whether an ER $\beta 1$-mutant p53 binding occurs, we performed co-immunoprecipitation (CoIP) experiments in lysates from $\mathrm{p} 53280 \mathrm{~K}$-expressing MDA-MB-231 and p53143A-transfected H1299 cells. As shown in Figure $3 \mathrm{~A}$, an interaction between ER $\beta 1$ and p53 mutants was observed in both MDA-MB-231 and H1299 cells. In addition to transfected ER $\beta 1$, mutant p53 bound to endogenously expressed receptor in MCF-7 cells (Figure $3 \mathrm{~A}$, right). To define the interacting regions of the two proteins we examined a series of N-terminal, 

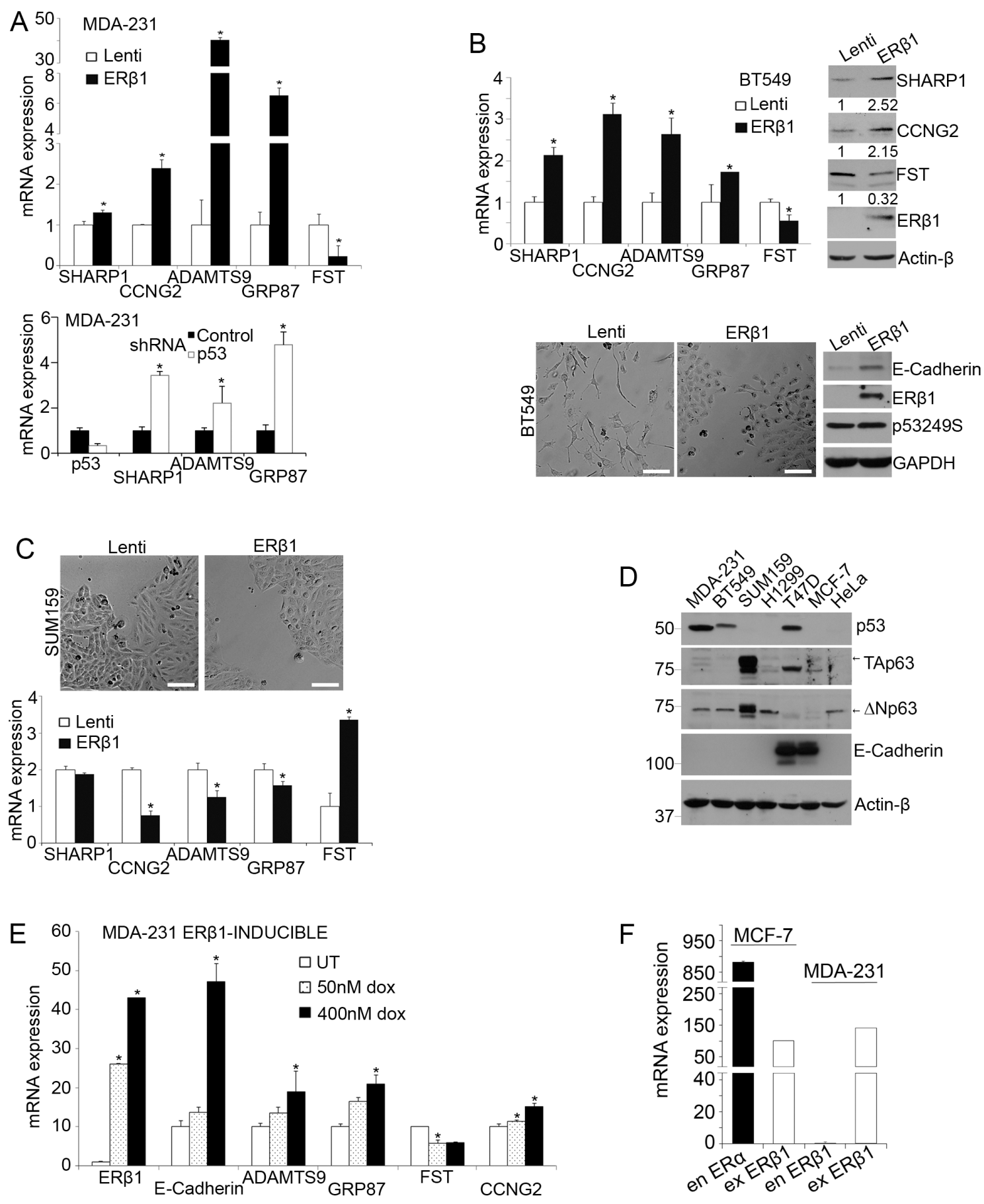

Figure 1: ERß1 regulates mutant p53 target genes. (A-C) TNBC cells were stably infected with lentivirus containing an empty vector (Lenti) or pLenti-FLAG-ER $\beta 1$ plasmid (ER $\beta 1)$. (A) Top: The mRNA levels of mutant p53 target genes were quantified in control (Lenti) and ER $\beta 1$-expressing MDA-MB-231 (MDA-231) cells by real-time PCR and normalized to control cells (Follistatin, FST). Values are mean \pm standard deviation (S.D.) of three independent experiments; ${ }^{*} P \leq 0.05$. Bottom: mRNA levels of mutant $\mathrm{p} 53$ target genes in MDA-MB-231 cells after transfection with p53shRNA. (B) Top: mRNA and protein levels of mutant p53 target genes in control and ER $\beta 1$ expressing BT549 cells. Band intensities were analyzed by densitometry and normalized to Actin- $\beta$. The numbers under each immunoblot show the fold change compared to the control cells and represent the median of three experiments. Bottom: Morphology (left) and protein levels of ER $\beta 1$, mutant p53249S and E-cadherin (right) in control and ER $\beta 1$-expressing BT549 cells (scale bars, $100 \mu \mathrm{m}$ ). (C) Morphology (top) and mRNA levels of mutant p53 target genes (bottom) of control and ER $\beta 1$-expressing p53 null SUM159 cells. Values represent the mean \pm S.D. of three independent experiments; $* P \leq 0.05$. (D) Protein levels of p53, TAp63, $\Delta$ Np63 and E-cadherin in wild-type cell lines. (E) MDA-MB-231 cells were stably infected with lentivirus containing the pINDUCER-FLAG-ER $\beta 1$ plasmid and left untreated (UT) or treated with $50 \mathrm{nM}$ or $400 \mathrm{nM}$ doxycycline for $24 \mathrm{~h}$ for gradual induction of ER $\beta 1$ expression. Graph indicates the mean of three experiments; ${ }^{*} P \leq 0.05$. (F) mRNA levels of exogenous (ex) ER $\beta 1$ in MCF-7 and MDA-MB-231 cells are compared with those of endogenous (en) ER $\alpha$ in MCF-7 cells. Graph shows the mean of three independent experiments. 
C-terminal and DBD deletion mutants of ER $\beta 1$ and p53143A. Analysis of MDA-MB-231 cells expressing ER $\beta 1$ domains and H1299 cells expressing p53143A truncations revealed that the C-terminus (296-393 aa) of mutant p53 and AF2 of ER $\beta 1$ are indispensable for their interaction (Figure 3B and Supplementary Figure 2). GST pull-down experiments with GST fusion mutant p53 expressed in bacteria and in vitro translated ER $\beta$ deletion mutants confirmed the AF2 of ER $\beta 1$ as the mutant p53 interacting region (Figure $3 \mathrm{C}$ and $3 \mathrm{D}$ ). In addition to $\mathrm{ER} \beta 1$, the C-terminus of mutant p53 was previously shown to bind to many other proteins and is required for the inhibition of p63 function and promotion of invasion [3]. Given that mutant p53 is tethered to specific chromatin
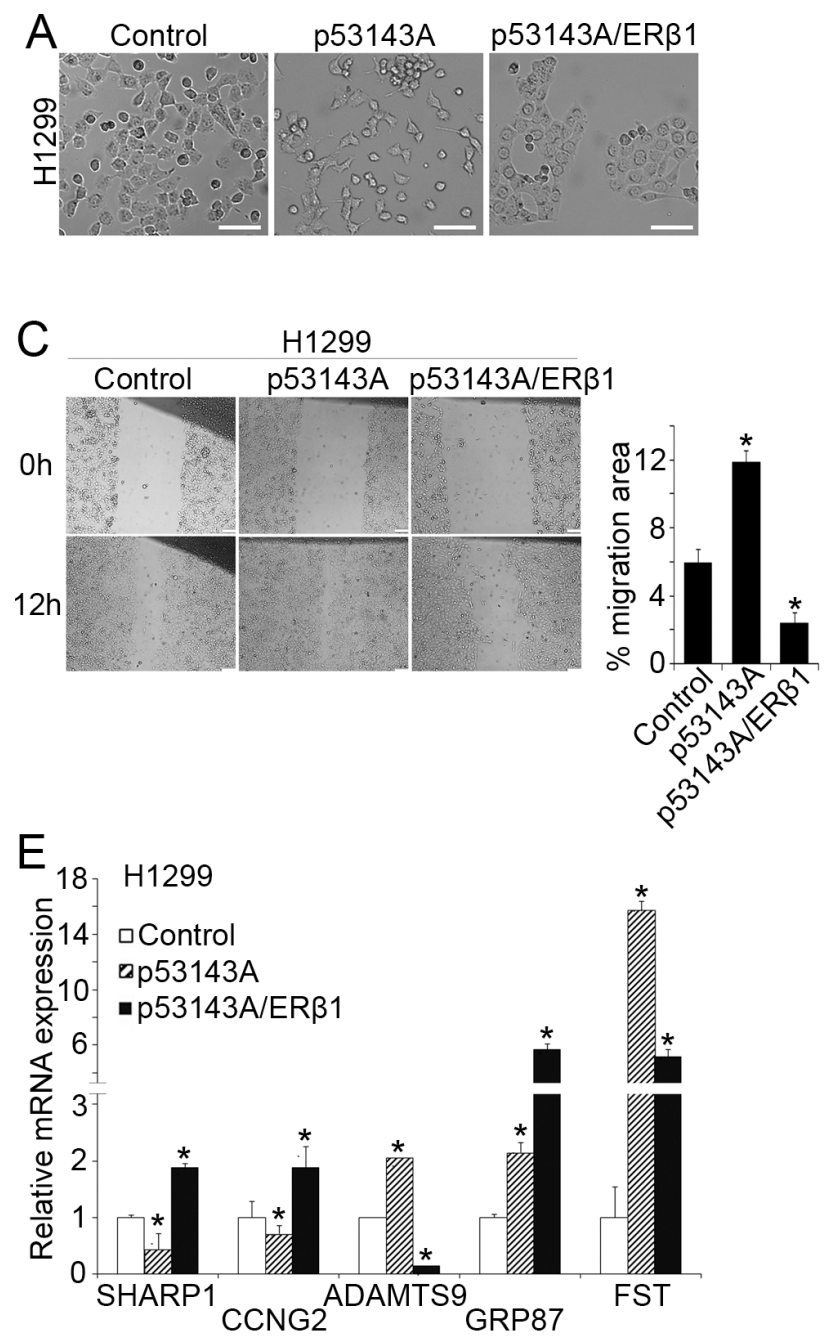

regions through p63 [16], we examined whether ER $\beta 1$ binds to p63. As shown in Figure 3E, p63 interacted with ER $\beta 1$ and silencing of p63 in MDA-MB-231 cells decreased the association of ER $\beta 1$ with mutant $\mathrm{p} 53$. These findings suggest a role for $\mathrm{p} 63$ in the regulation of the ER $\beta 1$-mutant p53 interaction. Furthermore, we tested whether the AF2 of ER $\beta 1$ alone is able to suppress mutant p53 function. As shown in Figure 3F (top), the expression patterns of two of the mutant p53 target genes (GRP87, Follistatin) in AF2expressing MDA-MB-231 cells were similar with those in cells expressing full length ER $\beta 1$. This was associated with the more epithelial-like morphology of AF2-expressing cells, suggesting that the AF2 is essential for the effect of ER $\beta 1$ on mutant p53 function (Figure 3F, bottom).
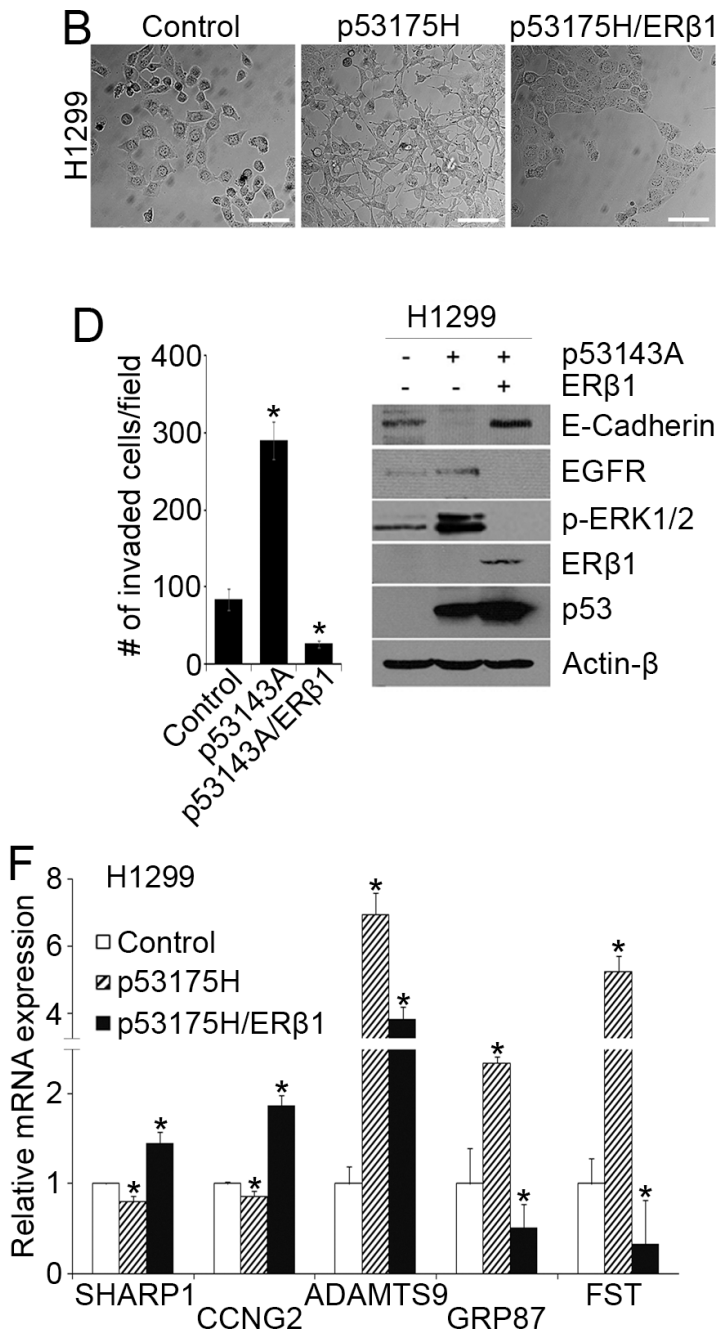

Figure 2: ERß1 decreases cell invasion by regulating mutant p53 target genes. (A-B) H1299 cells after stable transfection with empty vectors (control), or recombinant mutant p53143A or p53143A and ER $\beta 1$ plasmids (A) as well as mutant p53175H or p53175H and ER $\beta 1$ plasmids (B) (scale bars, $100 \mu \mathrm{m}$ ). (C) Left: Migration in control, p53143A- and p53143A/ER $\beta 1$-expressing H1299 pooled colony cells was assessed with wound-healing assay. Right: The area of cell migration in the wound was measured at the time of scratching the cell monolayer and $12 \mathrm{~h}$ later using ImageJ software. Values represent the mean \pm S.D. of fold changes in migration area $(12 \mathrm{~h} / 0 \mathrm{~h})$ from three experiments; ${ }^{*} P \leq 0.05$. (D) Left: Invasion was assessed in control, p53143A- and p53143A/ER $\beta 1$-expressing H1299 cells with matrigel-coated Transwell chambers. The cells that invaded were quantified in five independent fields. The graph indicates the mean (cell number per field) of three experiments; ${ }^{*} P \leq 0.05$ indicated. Right: E-cadherin, EGFR and phospho-ERK1/2 levels in control, p53143A- or p53143A/ERß1-expressing H1299 cells. (E-F) mRNA levels of mutant p53 target genes in control, p53143A-, p53143A/ERß1-, p53175Hand p53175H/ER $\beta 1$-expressing H1299 cells (Follistatin, FST). 


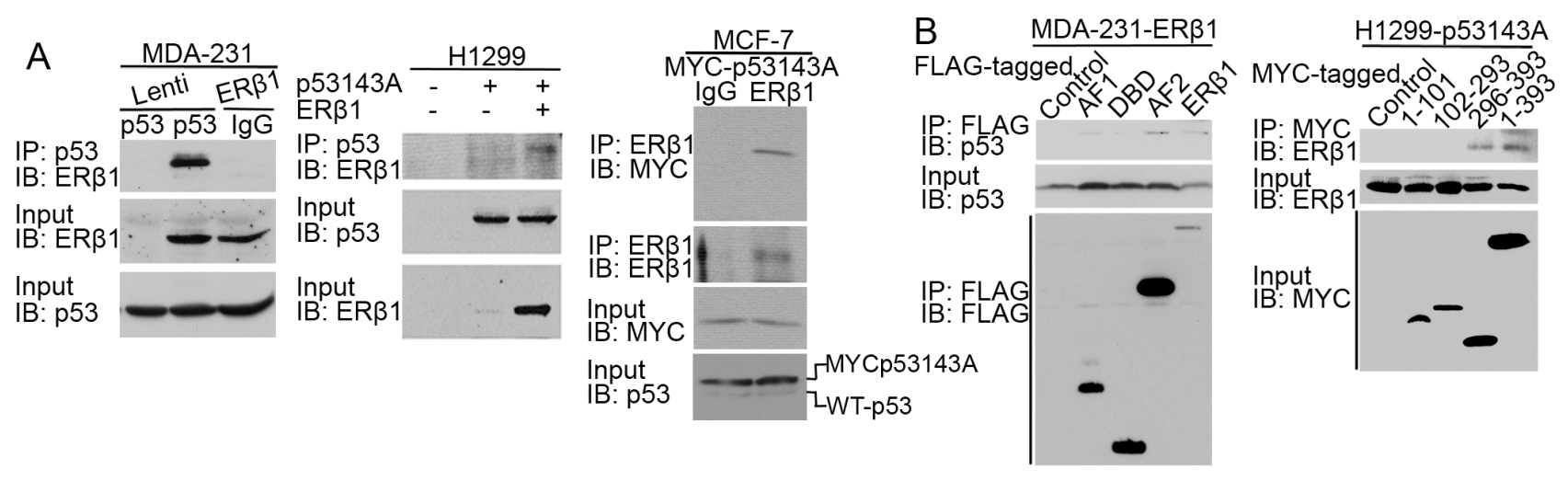

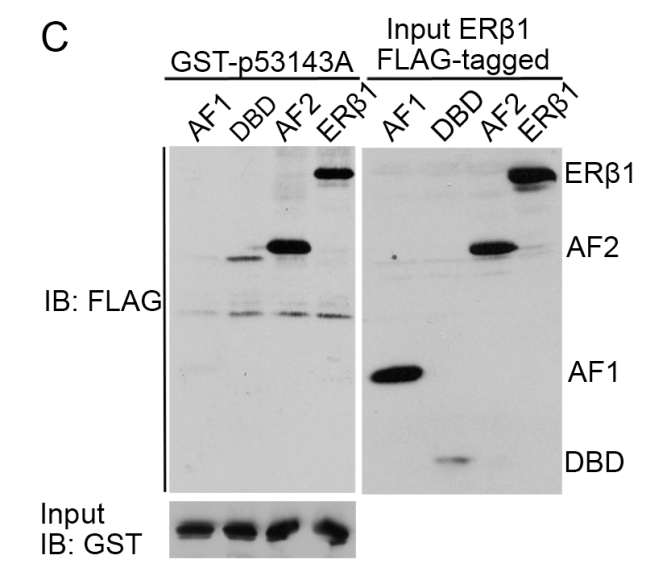
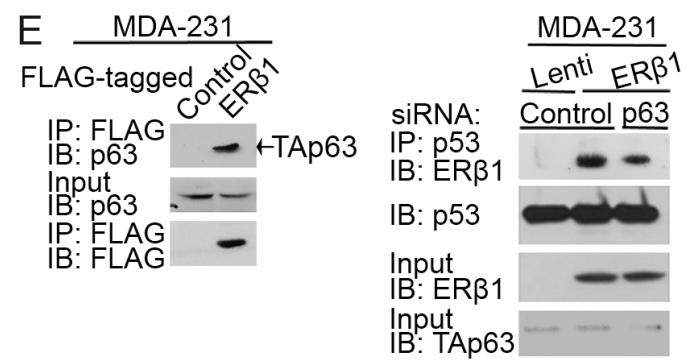

D

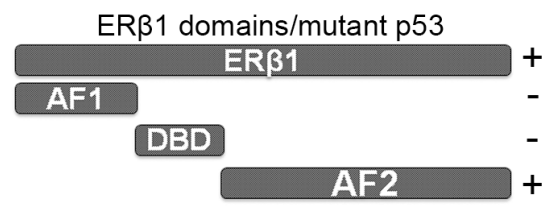

p53143 domains/ERß1

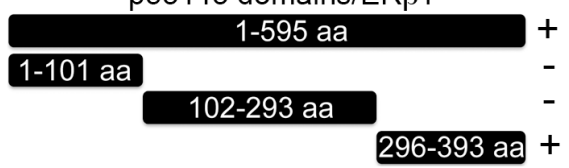

$\mathrm{F}$

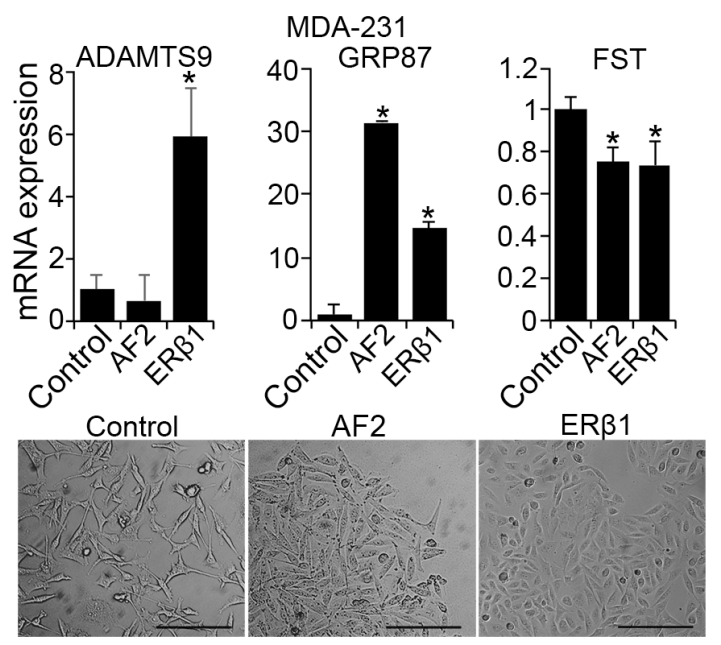

Figure 3: ERß1 interacts with mutant p53 and p63. (A) Lysates from control and ER $\beta 1$-expressing MDA-MB-231 cells (left) or control, p53143A-, and p53143A/ERß1-expressing H1299 cells (middle) were immunoprecipitated with anti-p53 antibody, followed by immunoblotting with ER $\beta 1$ antibody. Right: Lysates from MCF-7 cells transfected with MYC-p53143A were immunoprecipitated with anti-ER $\beta 1$ antibody or IgG, followed by immunoblotting with anti-MYC or anti-ER $\beta 1$ antibodies. The bottom panels are the input controls of cell lysates. (B) Left: Lysates from MDA-MB-231 cells stably expressing FLAG-tagged full-length ER $\beta 1$ or its activation function 1 (AF1), DNA-binding (DBD) and activation function 2 (AF2) domains were immunoprecipitated with anti-FLAG antibody, followed by immunoblotting with anti-p53 and anti-FLAG antibodies. Right: Lysates from H1299 cells stably co-transfected with empty vectors (control) or full-length ER $\beta 1$ together with MYC-tagged full-length mutant p53143A or its N-terminal (1-101 aa), DBD (102-293 aa) and C-terminal (296-393 aa) domains were immunoprecipitated with anti-MYC antibody followed by immunoblotting with anti-ER $\beta 1$ antibody. (C) GST-tagged p53V143A expressed in bacteria was used as bait protein to capture in pull-down assay in vitro translated FLAG-tagged full-length ER $\beta 1$ or its AF1, DBD and AF2 domains. (D) Schematic representation of ER $\beta 1$ truncations interacting with mutant p53 (top) and mutant p53 truncations interacting with full-length ER $\beta 1$ (bottom). (E) Left: Lysates from control and FLAG-tagged ER 31 -expressing MDA-MB-231 cells were immunoprecipitated with anti-FLAG antibody, followed by immunoblotting with anti-p63 and anti-FLAG antibodies. Right: Lysates from control and ER 31 -expressing MDA-MB-231 cells after transfection with control or p63 siRNA (\#1) were immunoprecipitated with anti-p53 antibody, followed by immunoblotting with ER $\beta 1$ antibody. (F) mRNA levels of ADAMTS9, GRP87 and Follistatin (FST) (top) and morphology (bottom) of MDA-MB-231 cells expressing full-length ER $\beta 1$ or its AF2 domain (scale bars, $200 \mu \mathrm{m})$. 


\section{p63 affects the regulation of mutant p53 function by ERß1}

p53 mutants have been shown to promote invasion by preventing normal TAp63 function $[10,12,28]$. Given that ER $\beta 1$ inhibited both invasion and mutant $\mathrm{p} 53$ function in TNBC cells, we investigated whether activation of TAp63 is essential for the anti-invasive activity of ER $\beta 1$. We initially found that ER $\beta 1$ alters the expression of the p63 target genes K14 and BCL-2 in MDA-MB-231 cells that express both TA and $\triangle \mathrm{Np} 63$ (Figure 4A and 1D) [37]. Importantly, transfection with siRNA that downregulates both p63 isoforms reversed to a significant extent the epithelial-like morphology and upregulation of E-cadherin in ER $\beta 1$-expressing MDA-MB-231 cells (Figure 4B and 4C and Supplementary Figure 3) [27]. In addition, knockdown of p63 significantly reversed the ER $\beta 1$-induced expression of the mutant $\mathrm{p} 53$ target genes SHARP-1, ADAMTS9 and CCNG2. In contrast, the levels of Follistatin were further decreased which may reflect a different effect of TAp63 and $\Delta \mathrm{Np} 63$ downregulation on the expression of some of the ER $\beta 1 /$ mutant $p 53$-regulated genes (Figures $4 \mathrm{C}$ and $1 \mathrm{~A}$ ). These results suggest that p63 is involved in the mechanism employed by ER $\beta 1$ to inhibit the invasive phenotype of TNBC cells and are consistent with the regulation of mutant $\mathrm{p} 53$-ER $\beta 1$ interaction by p63 (Figure 3E). To examine whether ER $\beta 1$ regulates p63 target genes in a mutant p53-independent manner, we analyzed the expression of SHARP-1, CCNG2 and Follistatin in p53 null H1299 cells that express endogenous p63 (Figure 1D). As shown in Figure 4D and $4 \mathrm{E}$, upregulation of ER $\beta 1$ altered the expression of these genes and the morphology of cells in absence of p53, albeit to a lesser degree than in presence of mutant p53 suggesting that ER $\beta 1$ can directly act on p63.

\section{ERß1 interferes with the regulatory elements of mutant p53/p63 target genes}

Given the binding of ER $\beta 1$ to both mutant p53 and $\mathrm{p} 63$, we investigated whether ER $\beta 1$ interacts with regulatory elements of mutant p53/p63 target genes. We performed chromatin-immunoprecipitation (ChIP) experiments in MDA-MB-231 cells to examine whether ER $\beta 1$ binds to sites that contain either both ERE and p53REs or exclusively ERE within the promoter region and close to the first exon of ADAMTS9, GRP87 and Follistatin genes (Supplementary Figure 4). We also analyzed ERE/p53REs-negative sites from $36 B 4$ promoter and downstream of the ADAMTS9 gene as well as a $5^{\prime}$ p53RE from CDKN1A ( 221$)$ promoter that binds to wild-type p53 [38]. As shown in Figure 5A, a strong association of ER $\beta 1$ with ERE/p53REs-containing sites of ADAMTS9, GRP87 and Follistatin was detected in ER $\beta 1$-expressing cells. The association of ER $\beta 1$ with the ERE-containing sites of the same genes was also induced in ER $\beta 1$-expressing cells, albeit at significantly lower degree in case of ADAMTS9 and Follistatin. These results suggest that both direct DNA binding and interaction with mutant p53 may be necessary for ER $\beta 1$ to associate with promoters of mutant p53 target genes (Figure 5A).

To examine whether upregulation of ER $\beta 1$ alters the binding of mutant $\mathrm{p} 53$ to promoters of its target genes, we performed ChIP for $\mathrm{p} 53$ in control and ER $\beta 1$-expressing MDA-MB-231 cells. As shown in Figure 5B, in contrast to $p 21$ promoter, the association of mutant $\mathrm{p} 53$ with ADAMTS9, GRP87 and Follistatin sites was dramatically induced in ER $\beta 1$-expressing cells. This suggests that ER $\beta 1$ may specifically increase the binding of mutant p53 to genes that are associated with metastasis. An enrichment of the mutant $\mathrm{p} 53$-bound sequences that contain exclusively ERE motifs was also observed in ER $\beta 1$-expressing cells, suggesting that mutant p53 may tether to specific DNA sequences through ER $\beta 1$ (Figure 5B).

To examine whether p63 alters the binding of ER $\beta 1$ to regulatory elements of mutant p53 target genes, we performed ChIP in ER 31 -expressing MDA-MB-231 cells following knockdown of p63. As shown in Figure 5C, the binding of ER $\beta 1$ to ERE/p53REs of ADAMTS9, GRP87 and Follistatin promoters was induced by p63 downregulation. In contrast, p63 knockdown decreased the ER $\beta 1$ association with the ERE motif of GRP87 promoter suggesting that p63 may regulate direct ER $\beta 1$-DNA binding (Figure 5C). Taken together, these results suggest an interaction of ER $\beta 1$ with promoters of mutant p 53 target genes, which is regulated by mutant $\mathrm{p} 53$ and p63.

\section{Effects of ligands on ERß1-mutant p53 interaction}

Upregulation of ER $\beta 1$ in cancer cells elicits tumor repressive actions in both ligand-dependent and -independent manner. Similarly, ligand-dependent and -independent target genes were identified in ER $\beta 1$-expresing cancer cells $[27,34,39-41]$. In this study, we investigated whether ligands that bind $E R \beta 1$ alter the function of mutant $p 53$. The ER $\beta 1$ agonists $17 \beta$-estradiol (E2), $5 \alpha$-androstane- $3 \beta, 17 \beta-$ diol (3ß-Adiol) and Diarylpropionitrile (DPN) but not the $\mathrm{ER} \alpha$ antagonist tamoxifen significantly increased the EREdependent transcription in ER $\beta 1$-expressing MDA-MB-231 cells (Figure 6A). In contrast, tamoxifen significantly increased the expression of all the mutant p53 target genes in ER $\beta 1$-expressing cells but not in control cells (Figure 6B and $6 C$ ). This may suggest that tamoxifen increases ER $\beta 1$ transcriptional responses when the receptor cooperates with other transcription factors. In addition to tamoxifen, the ER $\beta 1$-selective agonist DPN altered the expression of SHARP-1, CCNG2 and Follistatin but not ADAMTS9 and GRP87 in the same mode as the upregulation of ER $\beta 1$ did (Figure 6B and 6C and Figure 1A and 1B). These results support the presence of a functional receptor in TNBC cells and the ability of ER ligands to regulate mutant p53 function. 


\section{DISCUSSION}

In the present study we examined whether inhibition of mutant p53 oncogenic function accounts for the decreased invasiveness of ER $\beta 1$-expressing TNBC cells. We found that ER $\beta 1$ upregulates mutant p53 target genes that are associated with normal phenotype and decreases the expression of pro-metastatic factors. This effect was observed in TNBC and other human cancer cell lines that harbor different tumor-associated p53 mutations, indicating the ability of the receptor to alter mutant $\mathrm{p} 53$ dependent transcription across different forms of mutant p53. Small divergence in the expression of some of the p53 target genes across ER $\beta 1$-expressing cell lines may be attributed to the different function of mutant p53 in cells with varying expression of TA and $\triangle \mathrm{Np} 63$ and other cofactors.

We also examined whether an ER $\beta 1$-mutant p53 interaction is required to modify the mutant $\mathrm{p} 53$ function. A strong binding of ER $\beta 1$ to different p53 mutants was observed in triple-negative and other types of cancer cells. Further analysis revealed that the AF2 domain of ER $\beta 1$ interacts with the $\mathrm{C}$-terminus of mutant $\mathrm{p} 53$. This region of mutant p53 binds to many other proteins $[42,43]$ and
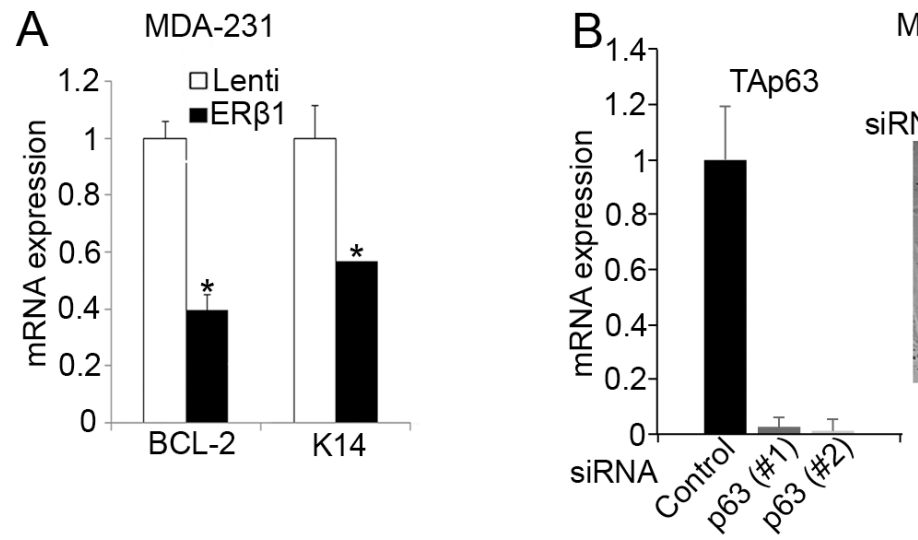

MDA-231-ERß1

siRNA: Control

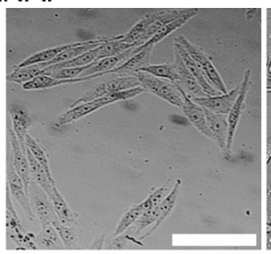

p63 (\#1)

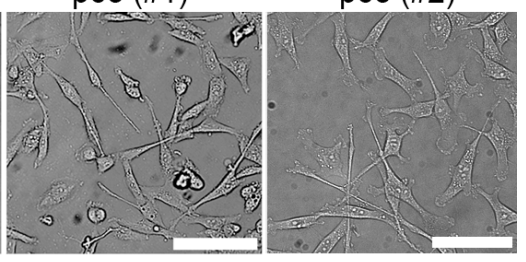

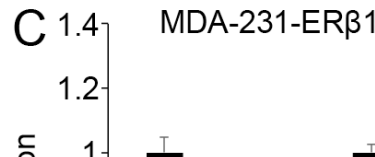
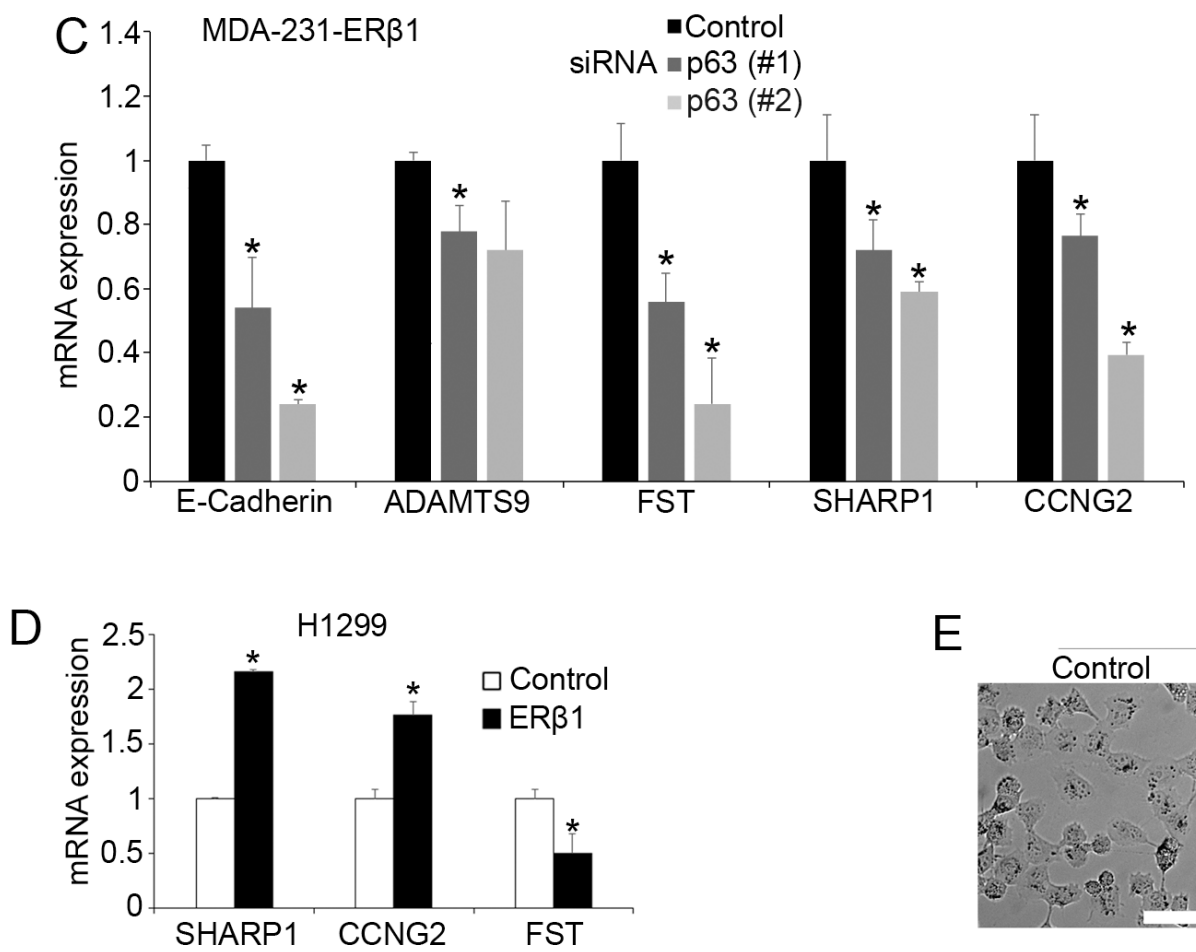

E

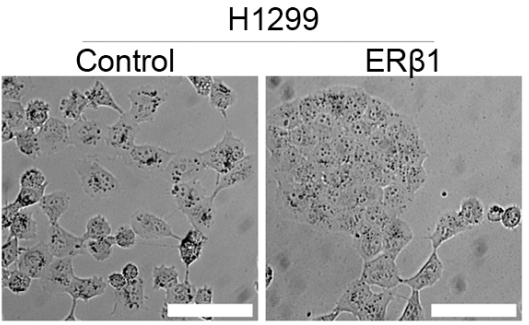

Figure 4: p63 affects the regulation of mutant p53 by ERß1. (A) mRNA levels of the p63 target genes $K 14$ and $B C L-2$ in control and ER $\beta 1$-expressing MDA-MB-231 cells. The graph shows the mean of three experiments; $* P \leq 0.05$. (B) Levels of TAp63 and morphology of ER $\beta 1$-expressing MDA-MB-231 cells following transfection with control or two siRNAs targeting p63 (scale bars, $100 \mu \mathrm{m}) .(\mathbf{C})$ mRNA levels of E-cadherin and mutant p53 target genes in ER $\beta 1$-expressing MDA-MB-231 cells after transfection with p63 siRNA (Follistatin, FST). Values represent the mean \pm S.D. of three experiments; ${ }^{*} P \leq 0.05$. (D-E) mRNA levels of mutant p53 target genes and morphology of control and ER $\beta 1$-expressing H1299 cells (scale bars, $100 \mu \mathrm{m}$ ). 

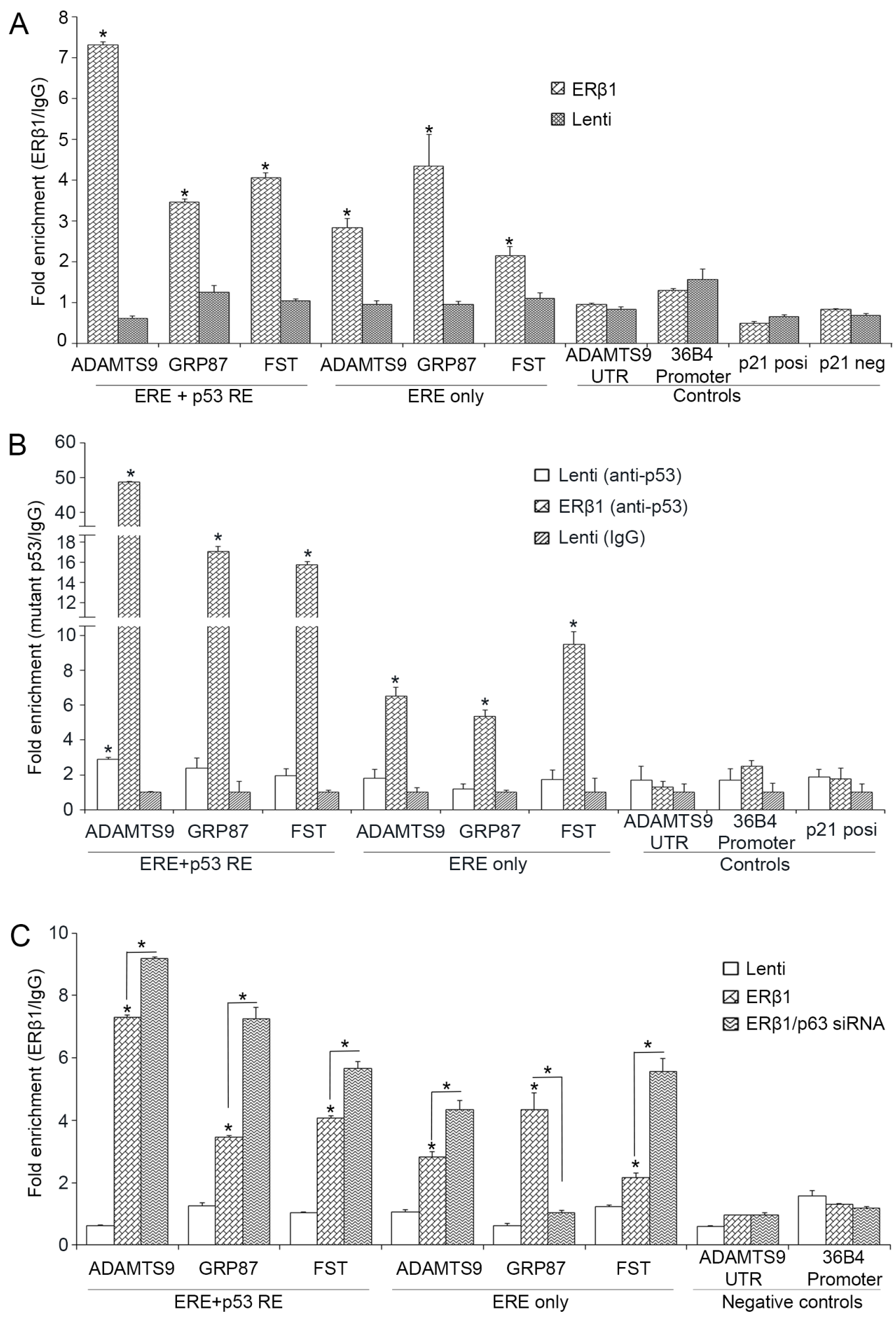

Figure 5: ERß1 binds to promoters of mutant p53 target genes. (A) Chromatin immunoprecipitation (ChIP) analysis in control and ER $\beta 1$-expressing MDA-MB-231 cells for the presence of ER $\beta 1$ at sites of mutant p53 target genes that contain both ERE and p53REs or exclusively ERE (Follistatin, FST). ERE/p53REs-negative sites from $36 B 4$ promoter and downstream of the ADAMTS9 gene and a $5^{\prime}$ p53RE from $p 21$ promoter that binds wild-type p53 were used as controls. Anti-FLAG antibody was used to immunoprecipitate ER $\beta 1$ and normal mouse IgG was used as experimental control. Fold enrichment of p53 target sequences was normalized to IgG ChIP. (B) ChIP analysis for binding of mutant p53 at sites of mutant p53 target genes in control and ER $\beta 1$-expressing MDA-MB-231 cells. (C) ChIP analysis for the presence of ER $\beta 1$ at sites of mutant p53 target genes in control and ER $\beta 1$-expressing MDA-MB-231 cells following transfection with control or p63 siRNA (\#1). Fold enrichment of target sequences in ER $\beta 1$ precipitates was normalized to that of IgG precipitates. All graphs represent the mean \pm SEM of three experiments; $* P \leq 0.05$. 
inhibits the function of p63 [18]. Our experiments showed that ER $\beta 1$ interacts with p63. This suggests that ER $\beta 1$ may repress mutant p53 function through its recruitment to mutant p53-p63 complexes at promoters of mutant p53/p63 target genes (Figure 6D). ChIP assays confirmed the association of ER $\beta 1$ with such promoters through both direct binding and tethering mechanisms. The direct binding is also supported by the ability of ER $\beta 1$ to regulate the same genes in absence of p53. Importantly, ER $\beta 1$ was also found to increase the association of mutant p53 with p53REs. Wild-type p53 binds the same promoters [16] and mutant $\mathrm{p} 53$ shows impaired binding to standard p53REs [3]. Thus, our findings may imply that the ER $\beta 1$-mutant p53 interaction readjusts the folding of mutant protein into a wild-type conformation that leads to reactivation of wild-type function. Notably, binding of mutant p53 to ERE motifs of the same promoters in the presence of ER $\beta 1$ suggests that mutant p53 may regulate ER $\beta 1$ transcriptional activity. This model of mutant p53 function was previously described with other transcription factors [3].

In this study, we propose that the anti-invasive activity of ER $\beta 1$ in breast and perhaps in other types of cancer cells may correlate with its ability to interact with oncogenic mutant p53. The relevance of this interaction to breast cancer may depend on the expression of the two proteins in tumor cells. Although the expression of ER $\beta$ has been suggested to decline in invasive carcinomas [4446], a significant of number of breast tumors including TNBCs express the receptor $[19,21,47,48]$. In this study, lower levels of ER $\beta 1$ were found to interact with mutant p53 in TNBC cells compared with those of ER $\alpha$ that interact with wild-type p53 in ER $\alpha$-positive breast cancer cells $[24,25]$. Importantly, the ER $\beta 1$-mutant p53 binding was also detected in breast cancer cells that naturally express the receptor. The functionality of this interaction is supported by the ligand-dependent inhibition of mutant p53 function in ER $\beta 1$-expressing cells. This is consistent
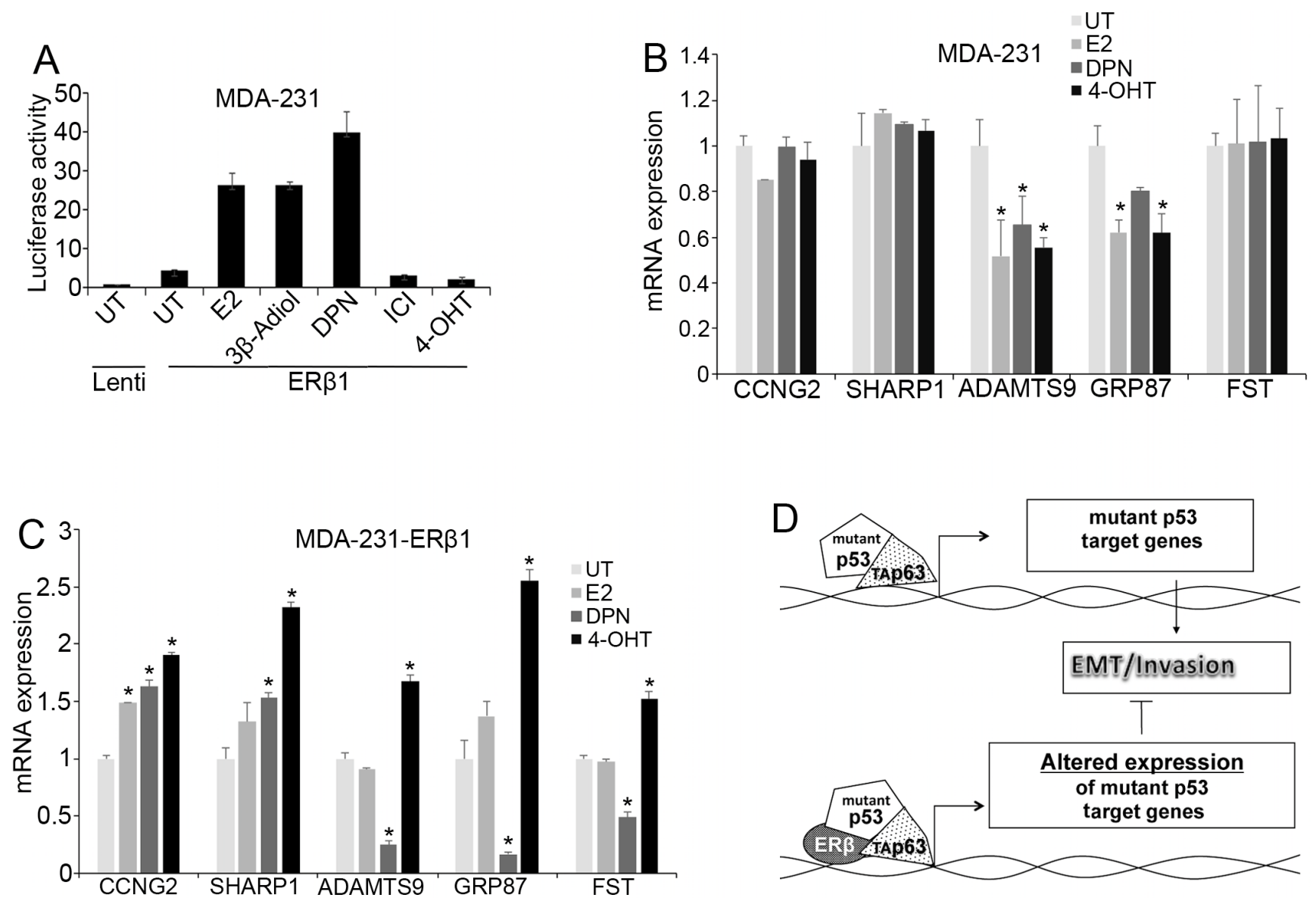

Figure 6: Effects of ER ligands on mutant p53 function. (A) ERE-driven luciferase activity in control and ER $\beta 1$-expressing MDAMB-231 cells after treatment with $10 \mathrm{nM} 17 \beta$-estradiol(E2), Diarylpropionitrile(DPN), ICI 182780 (ICI) or $1 \mu \mathrm{M} 5 \alpha$-androstane- $3 \beta, 17 \beta$-diol (3ß-Adiol) or 4-hydroxytamoxifen (4-OHT) for $24 \mathrm{~h}$. The graph indicates the mean \pm S.D. of three experiments. (B-C) mRNA levels of mutant p53 target genes in control (B) and ER 31 -expressing (C) MDA-MB-231 cells after treatment with $10 \mathrm{nM}$ E2, $10 \mathrm{nM}$ DPN or $1 \mu \mathrm{M} 4-\mathrm{OHT}$ in DCC-containing media for $24 \mathrm{~h}$ (Follistatin, FST). Values represent the mean \pm S.D. of three experiments; $* P \leq 0.05$. (D) Proposed mechanism illustrating the regulation of mutant $\mathrm{p} 53$ function by ER $\beta 1$ in breast cancer cells. Mutant p53 alters the activity of transcription factors including p63. This results in a gene expression program that promotes cell invasion. By interacting with mutant p53, ER $\beta 1$ alters mutant p53-dependent gene expression impeding EMT and inhibiting invasion. 
with the previously identified ligand-dependent ER $\beta 1$ target genes in TNBC cells [40]. Some of the ER ligands that act as ER $\alpha$ antagonists have been reported to induce ER $\beta 1$-mediated tumor repressive actions [40, 49-51]. The inhibitory effect of tamoxifen on mutant $\mathrm{p} 53$ function in the presence of ER $\beta 1$ suggests that patients whose p53defective breast tumors are positive for the receptor may benefit from treatment with ER ligands. This effect may also explain the previously reported association of ER $\beta 1$ with better survival in patients treated with tamoxifen [19]. Further understanding of the mechanism that regulates the occupancy of both proteins at promoters of common target genes should establish ER $\beta 1$ as an important regulator of mutant $\mathrm{p} 53$ oncogenic function in breast cancer.

\section{MATERIALS AND METHODS}

\section{Cells, reagents and constructs}

All cell lines were obtained from ATCC and cultured in RPMI-1460 or Dulbecco's Modified Eagle Medium media supplemented with $10 \%$ fetal bovine serum (FBS) at $37^{\circ} \mathrm{C}$ in $5 \% \mathrm{CO}_{2}$. Phenol redfree medium supplemented with $0.5-1 \%$ dextrancoated charcoal (DCC)-treated FBS was used in ligand treatments. For stable expression of ER $\beta 1$, cells were infected with pLenti6/V5-FLAG-ER $\beta 1$ construct as described previously [27]. The pINDUCER20-FLAGER $\beta 1$ plasmid was transduced into cells and gradual ER $\beta 1$ expression was achieved following incubation of G418-selected cells with different concentrations of doxycycline (dox) for 24 hours (h) [52]. Cells were single- or co-transfected with the following plasmids: pIRESneo3, pIRESpuro3 (Clontech), pIRESneo-FLAGER $\beta 1$, pIRESpuro-FLAG-p53V143A, pIRESpuro-FLAGp53V175H and pcDNA3-MYC-p53V143A. The cDNA of $\mathrm{p} 53 \mathrm{~V} 175 \mathrm{H}$ and $\mathrm{p} 53 \mathrm{~V} 143 \mathrm{~A}$ were $\mathrm{PCR}$-amplified from pCMV-Neo-Bam-p53V175H and -p53V143A plasmids (Addgene, plasmids \#16436 and 16435). FLAGtagged ER $\beta 1$ domains [AF1 (amino acids: 1-150), DBD (145-220), and AF2 (211-530)] were cloned into a pIRESneo3 vector and MYC-tagged p53V143A domains [N-terminus (1-101), DBD (102-293) and C-terminus (296-393)] into a pcDNA3 plasmid. The pGEX4T-1 plasmid was used for the bacterial expression of GST-tagged proteins. Cells were transfected twice with p63-specifc siRNAs from Invitrogen, target sequences: 1\# 5'-ATTCCATGGTCGTGTGAGACAGAAG-3' and 2\# 5'-AACTTAAGCGCCGAGTCGAGTACCA-3'. An siRNAtargeting luciferase was used as control (Cat. No. 12935146; Invitrogen). For p53 knockdown, cells were transfected twice with the pLKO-p53-shRNA-427 or scramble shRNA control plasmids (Addgene, plasmids \#25636 and 1864). All transfections were performed using Lipofectamine 2000 (Invitrogen) as previously described [27].

\section{RNA extraction, real-time quantitative reverse transcription (RT) PCR}

mRNA was isolated using the Aurum ${ }^{\mathrm{TM}}$ Total RNA Mini Kit (Biorad). RNA was reversed transcribed to cDNA using the iScript ${ }^{\mathrm{TM}}$ cDNA Synthesis Kit (Biorad). Real-time PCR was performed using the iTaq $^{\mathrm{TM}}$ Universal SYBr Green Supermix (Bio-Rad). All quantitative data were normalized to $36 \mathrm{~b} 4$. Primer sequences for the real-time PCR experiments are listed in Supplementary Table 1.

\section{Luciferase assays}

For assessing ERE-dependent transcriptional activity, cells were maintained in phenol red free DCCcontaining media for $48 \mathrm{~h}$, transiently co-transfected with 3-ERE-TATA-LUC reporter plasmid and a plasmid expressing $\beta$-galactosidase and incubated in the presence of ligands for $24 \mathrm{~h}$. Luciferase activity was measured as previously described [41].

\section{Co-immunoprecipitation and immunoblotting}

Cells were plated at a density of $5 \times 10^{5}-10^{6}$ per 10-cm dish and lysed in immunoprecipitation (IP) buffer containing $50 \mathrm{mM}$ Hepes $\mathrm{pH} 7.4,150 \mathrm{mM} \mathrm{NaCl}$, $1 \mathrm{mM}$ EDTA, $0.8 \mathrm{mM}$ EGTA, $1 \mathrm{mM}$ NP-40, $1 \mathrm{mM}$ Glycerol, $2 \mathrm{mM}$ PMSF, $1 \mathrm{mM} \mathrm{Na} \mathrm{VO}_{4}, 50 \mathrm{mM} \mathrm{NaF}, 1 \%$ protease inhibitor cocktail (Roche) and 1\% phosphatase inhibitor mixture (Sigma). Supernatants were clarified by centrifugation and incubated with specific antibodies overnight and $\mathrm{A} / \mathrm{G}$ agarose beads (Santa Cruz) or protein $\mathrm{G}$ magnetic beads (Biorad) for $3 \mathrm{~h}$. Immunoprecipitates were subjected to SDS-PAGE and transferred onto nitrocellulose membrane (Amersham Biosciences). Membranes were probed with the primary antibodies overnight at $4^{\circ} \mathrm{C}$ and proteins were visualized using ECL detection kit (Amersham Biosciences) as previously described [39]. ER $\beta 1$ and its truncations were immunoprecipitated with anti-FLAG M2 affinity gel (Sigma) and the precipitates were immunoblotted with a rabbit antibody against p53 (Cell signaling). For the reverse experiments, antibodies against p53 (DO-1 or Pab 240; Santa Cruz) were used for immunoprecipitation and ER $\beta 1$ antibodies (rabbit polyclonal, Millipore or 14C8, GeneTex) for immunoblotting. MYC-tagged p53V143A and its truncations were immunoprecipitated with anti-MYC antibody (Cell signaling). Antibodies against p63 and $\triangle \mathrm{Np} 63$ were from Abcam (BC4A4) and Biolegend, respectively. Antibodies against SHARP-1, Follistatin were from Santa Cruz and that of CCNG2 from Abcam. 


\section{Chromatin immunoprecipitation}

Protein-DNA complexes were crosslinked with $1 \%$ formaldehyde for $10 \mathrm{~min}$ at room temperature (RT). Cells were harvested and cell suspensions were centrifuged. For nuclei purification, cell pellets were washed (PBS, NCP1 and NCP2 buffers) and incubated in lysis buffer $(10 \mathrm{mM}$ EDTA, $20 \mathrm{mM}$ Tris- $\mathrm{HCl} \mathrm{pH}$ 8.1, $0.5 \mathrm{mM}$ Empigen, $1 \mathrm{mM}$ SDS and $1 \%$ protease inhibitor mixture) for $10 \mathrm{~min}$ at RT. Chromatin in the nuclear extract was sheared by sonication, clarified by centrifugation and the supernatant was used for immunoprecipitation as previously described [53]. Chromatin-bound mutant p53 was incubated with an anti-p53 antibody or $\operatorname{IgG}$ and precipitated with protein G magnetic beads. Anti-FLAG M2 magnetic beads (Sigma) were used for the precipitation of the chromatinbound ER $\beta 1$. Protein-DNA complexes were eluted and decrosslinked at $70^{\circ} \mathrm{C}$ overnight and DNA enrichment was measured by real-time PCR using promoter-specific primers (Supplementary Table 1).

\section{Protein expression and GST pull-down assay}

GST-tagged proteins were produced as described previously [54]. Briefly, isopropyl $\beta$-D-1thiogalactopyranoside (IPTG) was added to the culture of transformed bacterial cells with pGEX4T-1-p53143A recombinant plasmid to induce expression of GST-tagged protein. Protein interaction was assessed using a GST pulldown kit (Thermo Scientific) according to the manufacturer's protocol. GST-tagged proteins were used as bait to capture the full length or ER $\beta 1$ truncations that were expressed in vitro using the $\mathrm{TnT}^{\circledR}$ Quick Coupled Transcription/ Translation System (Promega). Glutathione agarose beads were used to precipitate the GST-tagged protein complexes overnight. The interacting proteins were eluted and subjected for analysis to SDS-PAGE and immunoblotting.

\section{Migration and invasion assays}

In the wound-healing assay, the cell monolayer was scratched with a pipette tip to form the wound. Images of the wound were taken when the cells were scraped and $12 \mathrm{~h}$ later, and the area of cell migration in the wound was measured. Invasion assay was performed as described previously [27]. Cells were plated in matrigel-coated $6.5 \mathrm{~mm}$ Transwell champers (BD Biosciences). $6 \mathrm{~h}$ later, the cells that had been invaded through the filter and attached to its bottom surface were stained with crystal-violet and counted in five independent fields in each Transwell.

\section{Statistical analysis}

Student's $t$-test and ANOVA were used for statistical analysis. Statistical significance was obtained when $p$-value $\leq 0.05$.

\section{ACKNOWLEDGMENTS}

We thank Chin-Yo Lin and Nicholes Candelaria for technical assistance with ChIP analysis. We also thank Daniel Frigo, Anders Strom and Laure Maneix for technical advice.

\section{GRANT SUPPORT}

This study was supported by grants from the Swedish Cancer Society and Robert A. Welch Foundation (E-0004).

\section{CONFLICTS OF INTEREST}

The authors declare no conflicts of interest.

\section{Editorial note}

This paper has been accepted based in part on peer-review conducted by another journal and the authors' response and revisions as well as expedited peer-review in Oncotarget.

\section{REFERENCES}

1. Cancer Genome Atlas Network. Comprehensive molecular portraits of human breast tumours. Nature. 2012; 490:61-70.

2. Hudis CA, Gianni L. Triple-negative breast cancer: an unmet medical need. Oncologist. 2011; 16:1-11.

3. Muller PA, Vousden KH. p53 mutations in cancer. Nature cell biology. 2013; 15:2-8.

4. Sigal A, Rotter V. Oncogenic mutations of the p53 tumor suppressor: the demons of the guardian of the genome. Cancer Research. 2000; 60:6788-6793.

5. Olive KP, Tuveson DA, Ruhe ZC, Yin B, Willis NA, Bronson RT, Crowley D, Jacks T. Mutant p53 gain of function in two mouse models of Li-Fraumeni syndrome. Cell. 2004; 119:847-860.

6. Lang GA, Iwakuma T, Suh YA, Liu G, Rao VA, Parant JM, Valentin-Vega YA, Terzian T, Caldwell LC, Strong LC, El-Naggar AK, Lozano G. Gain of function of a p53 hot spot mutation in a mouse model of Li-Fraumeni syndrome. Cell. 2004; 119:861-872.

7. Stindt MH, Muller PA, Ludwig RL, Kehrloesser S, Dotsch V, Vousden KH. Functional interplay between MDM2, p63/p73 and mutant p53. Oncogene. 2015; 34:4300-4310.

8. Natan E, Joerger AC. Structure and kinetic stability of the p63 tetramerization domain. J Mol Biol. 2012; 415:503-513.

9. Ethayathulla AS, Tse PW, Monti P, Nguyen S, Inga A, Fronza G, Viadiu H. Structure of p73 DNA-binding domain tetramer modulates p73 transactivation. Proceedings of the National Academy of Sciences of the United States of America. 2012; 109:6066-6071. 
10. Adorno M, Cordenonsi M, Montagner M, Dupont S, Wong C, Hann B, Solari A, Bobisse S, Rondina MB, Guzzardo V, Parenti AR, Rosato A, Bicciato S, et al. A Mutant-p53/ Smad complex opposes p63 to empower TGFbeta-induced metastasis. Cell. 2009; 137:87-98.

11. Gressner O, Schilling T, Lorenz K, Schulze Schleithoff E, Koch A, Schulze-Bergkamen H, Lena AM, Candi E, Terrinoni A, Catani MV, Oren M, Melino G, Krammer PH, et al. TAp63alpha induces apoptosis by activating signaling via death receptors and mitochondria. The EMBO journal. 2005; 24:2458-2471.

12. Muller PA, Caswell PT, Doyle B, Iwanicki MP, Tan EH, Karim S, Lukashchuk N, Gillespie DA, Ludwig RL, Gosselin P, Cromer A, Brugge JS, Sansom OJ, et al. Mutant p53 drives invasion by promoting integrin recycling. Cell. 2009; 139:1327-1341.

13. Su X, Chakravarti D, Cho MS, Liu L, Gi YJ, Lin YL, Leung ML, El-Naggar A, Creighton CJ, Suraokar MB, Wistuba I, Flores ER. TAp63 suppresses metastasis through coordinate regulation of Dicer and miRNAs. Nature. 2010; 467:986-990.

14. Di Como CJ, Gaiddon C, Prives C. p73 function is inhibited by tumor-derived p53 mutants in mammalian cells. Molecular and cellular biology. 1999; 19:1438-1449.

15. Gaiddon C, Lokshin M, Ahn J, Zhang T, Prives C. A subset of tumor-derived mutant forms of p53 down-regulate p63 and p73 through a direct interaction with the p53 core domain. Molecular and cellular biology. 2001; 21:1874-1887.

16. Neilsen PM, Noll JE, Suetani RJ, Schulz RB, Al-Ejeh F, Evdokiou A, Lane DP, Callen DF. Mutant p53 uses p63 as a molecular chaperone to alter gene expression and induce a pro-invasive secretome. Oncotarget. 2011; 2:1203-1217. doi: 10.18632/oncotarget.382.

17. Girardini JE, Napoli M, Piazza S, Rustighi A, Marotta C, Radaelli E, Capaci V, Jordan L, Quinlan P, Thompson A, Mano M, Rosato A, Crook T, et al. A Pin1/mutant p53 axis promotes aggressiveness in breast cancer. Cancer Cell. 2011; 20:79-91.

18. Noll JE, Jeffery J, Al-Ejeh F, Kumar R, Khanna KK, Callen DF, Neilsen PM. Mutant p53 drives multinucleation and invasion through a process that is suppressed by ANKRD11. Oncogene. 2012; 31:2836-2848.

19. Honma N, Horii R, Iwase T, Saji S, Younes M, Takubo K, Matsuura M, Ito Y, Akiyama F, Sakamoto G. Clinical importance of estrogen receptor-beta evaluation in breast cancer patients treated with adjuvant tamoxifen therapy. J Clin Oncol. 2008; 26:3727-3734.

20. Thomas C, Gustafsson JA. The different roles of ER subtypes in cancer biology and therapy. Nature reviews Cancer. 2011; 11:597-608.

21. Wang J, Zhang C, Chen K, Tang H, Tang J, Song C, Xie X. ERbetal inversely correlates with PTEN/PI3K/ AKT pathway and predicts a favorable prognosis in triplenegative breast cancer. Breast Cancer Res Treat. 2015; 152:255-269.
22. Menendez D, Inga A, Resnick MA. Estrogen receptor acting in cis enhances WT and mutant p53 transactivation at canonical and noncanonical p53 target sequences. Proceedings of the National Academy of Sciences of the United States of America. 2010; 107:1500-1505.

23. Liu W, Ip MM, Podgorsak MB, Das GM. Disruption of estrogen receptor alpha-p53 interaction in breast tumors: a novel mechanism underlying the anti-tumor effect of radiation therapy. Breast cancer research and treatment. 2009; 115:43-50.

24. Liu W, Konduri SD, Bansal S, Nayak BK, Rajasekaran SA, Karuppayil SM, Rajasekaran AK, Das GM. Estrogen receptor-alpha binds 53 tumor suppressor protein directly and represses its function. The Journal of biological chemistry. 2006; 281:9837-9840.

25. Sayeed A, Konduri SD, Liu W, Bansal S, Li F, Das GM. Estrogen receptor alpha inhibits p53-mediated transcriptional repression: implications for the regulation of apoptosis. Cancer Research. 2007; 67:7746-7755.

26. Samanta S, Sharma VM, Khan A, Mercurio AM. Regulation of IMP3 by EGFR signaling and repression by ERbeta: implications for triple-negative breast cancer. Oncogene. 2012; 31:4689-4697.

27. Thomas C, Rajapaksa G, Nikolos F, Hao R, Katchy A, McCollum CW, Bondesson M, Quinlan P, Thompson A, Krishnamurthy S, Esteva FJ, Gustafsson JA. ERbeta1 represses basal-like breast cancer epithelial to mesenchymal transition by destabilizing EGFR. Breast cancer research. 2012; 14:R148.

28. Muller PA, Trinidad AG, Caswell PT, Norman JC, Vousden KH. Mutant p53 regulates Dicer through p63dependent and -independent mechanisms to promote an invasive phenotype. The Journal of biological chemistry. 2014; 289:122-132.

29. Montagner M, Enzo E, Forcato M, Zanconato F, Parenti A, Rampazzo E, Basso G, Leo G, Rosato A, Bicciato S, Cordenonsi M, Piccolo S. SHARP1 suppresses breast cancer metastasis by promoting degradation of hypoxiainducible factors. Nature. 2012; 487:380-384.

30. Piccolo S, Enzo E, Montagner M. p63, Sharp1, and HIFs: master regulators of metastasis in triple-negative breast cancer. Cancer Research. 2013; 73:4978-4981.

31. Stossi F, Likhite VS, Katzenellenbogen JA, Katzenellenbogen BS. Estrogen-occupied estrogen receptor represses cyclin G2 gene expression and recruits a repressor complex at the cyclin G2 promoter. J Biol Chem. 2006; 281:16272-16278.

32. Kudo-Saito C, Fuwa T, Murakami K, Kawakami Y. Targeting FSTL1 prevents tumor bone metastasis and consequent immune dysfunction. Cancer Research. 2013; 73:6185-6193.

33. Du W, Wang S, Zhou Q, Li X, Chu J, Chang Z, Tao Q, $\mathrm{Ng}$ EK, Fang J, Sung JJ, Yu J. ADAMTS9 is a functional tumor suppressor through inhibiting AKT/mTOR pathway 
and associated with poor survival in gastric cancer. Oncogene. 2013; 32:3319-3328.

34. Nikolos F, Thomas C, Rajapaksa G, Bado I, Gustafsson JA. ERbeta Regulates NSCLC Phenotypes by Controlling Oncogenic RAS Signaling. Mol Cancer Res. 2014; 12:843-854.

35. El-Deiry WS, Kern SE, Pietenpol JA, Kinzler KW, Vogelstein B. Definition of a consensus binding site for p53. Nature Genetics. 1992; 1:45-49.

36. Hollstein M, Sidransky D, Vogelstein B, Harris CC. p53 mutations in human cancers. Science. 1991; 253:49-53.

37. Romano RA, Ortt K, Birkaya B, Smalley K, Sinha S. An active role of the DeltaN isoform of p63 in regulating basal keratin genes K5 and K14 and directing epidermal cell fate. PLoS One. 2009; 4:e5623.

38. Wei CL, Wu Q, Vega VB, Chiu KP, Ng P, Zhang T, Shahab A, Yong $\mathrm{HC}, \mathrm{Fu}$ Y, Weng Z, Liu J, Zhao XD, Chew JL, et al. A global map of $\mathrm{p} 53$ transcription-factor binding sites in the human genome. Cell. 2006; 124:207-219.

39. Rajapaksa G, Nikolos F, Bado I, Clarke R, Gustafsson JA, Thomas C. ERbeta decreases breast cancer cell survival by regulating the IRE1/XBP-1 pathway. Oncogene. 2015; 34:4130-4141.

40. Shanle EK, Zhao Z, Hawse J, Wisinski K, Keles S, Yuan M, $\mathrm{Xu}$ W. Research resource: global identification of estrogen receptor beta target genes in triple negative breast cancer cells. Mol Endocrinol. 2013; 27:1762-1775.

41. Thomas CG, Strom A, Lindberg K, Gustafsson JA. Estrogen receptor beta decreases survival of p53-defective cancer cells after DNA damage by impairing G/M checkpoint signaling. Breast cancer research and treatment. 2011; 127:417-427.

42. Do PM, Varanasi L, Fan S, Li C, Kubacka I, Newman V, Chauhan K, Daniels SR, Boccetta M, Garrett MR, Li R, Martinez LA. Mutant p53 cooperates with ETS2 to promote etoposide resistance. Genes \& development. 2012; 26:830-845.

43. Stambolsky P, Tabach Y, Fontemaggi G, Weisz L, MaorAloni R, Siegfried Z, Shiff I, Kogan I, Shay M, Kalo E, Blandino G, Simon I, Oren M, et al. Modulation of the vitamin D3 response by cancer-associated mutant p53. Cancer Cell. 2010; 17:273-285.

44. Huang B, Omoto Y, Iwase H, Yamashita H, Toyama T, Coombes RC, Filipovic A, Warner M, Gustafsson JA. Differential expression of estrogen receptor alpha, beta1, and beta 2 in lobular and ductal breast cancer. Proceedings of the National Academy of Sciences of the United States of America. 2014; 111:1933-1938.

45. Shaaban AM, O’Neill PA, Davies MP, Sibson R, West CR, Smith PH, Foster CS. Declining estrogen receptor-beta expression defines malignant progression of human breast neoplasia. Am J Surg Pathol. 2003; 27:1502-1512.
46. Skliris GP, Munot K, Bell SM, Carder PJ, Lane S, Horgan K, Lansdown MR, Parkes AT, Hanby AM, Markham AF, Speirs V. Reduced expression of oestrogen receptor beta in invasive breast cancer and its re-expression using DNA methyl transferase inhibitors in a cell line model. J Pathol. 2003; 201:213-220.

47. Marotti JD, Collins LC, Hu R, Tamimi RM. Estrogen receptor-beta expression in invasive breast cancer in relation to molecular phenotype: results from the Nurses' Health Study. Modern pathology. 2010; 23:197-204.

48. Shaaban AM, Green AR, Karthik S, Alizadeh Y, Hughes TA, Harkins L, Ellis IO, Robertson JF, Paish EC, Saunders PT, Groome NP, Speirs V. Nuclear and cytoplasmic expression of ERbeta1, ERbeta2, and ERbeta5 identifies distinct prognostic outcome for breast cancer patients. Clin Cancer Res. 2008; 14:5228-5235.

49. Reese JM, Suman VJ, Subramaniam M, Wu X, Negron V, Gingery A, Pitel KS, Shah SS, Cunliffe HE, McCullough AE, Pockaj BA, Couch FJ, Olson JE, et al. ERbeta1: characterization, prognosis, and evaluation of treatment strategies in ERalpha-positive and -negative breast cancer. BMC Cancer. 2014; 14:749.

50. Leung YK, Gao Y, Lau KM, Zhang X, Ho SM. ICI 182,780-regulated gene expression in DU145 prostate cancer cells is mediated by estrogen receptor-beta/ NFkappaB crosstalk. Neoplasia. 2006; 8:242-249.

51. Nakajima Y, Akaogi K, Suzuki T, Osakabe A, Yamaguchi C, Sunahara N, Ishida J, Kako K, Ogawa S, Fujimura T, Homma Y, Fukamizu A, Murayama A, et al. Estrogen Regulates Tumor Growth Through a Nonclassical Pathway that Includes the Transcription Factors ER \{beta\} and KLF5. Sci Signal. 4:ra22.

52. Meerbrey KL, Hu G, Kessler JD, Roarty K, Li MZ, Fang JE, Herschkowitz JI, Burrows AE, Ciccia A, Sun T, Schmitt EM, Bernardi RJ, Fu X, et al. The pINDUCER lentiviral toolkit for inducible RNA interference in vitro and in vivo. Proceedings of the National Academy of Sciences of the United States of America. 2011; 108:3665-3670.

53. Zhao C, Gao H, Liu Y, Papoutsi Z, Jaffrey S, Gustafsson JA, Dahlman-Wright K. Genome-wide mapping of estrogen receptor-beta-binding regions reveals extensive crosstalk with transcription factor activator protein-1. Cancer Research. 2010; 70:5174-5183.

54. Harper S, Speicher DW. Purification of proteins fused to glutathione S-transferase. Methods Mol Biol. 2011; 681:259-280. 